\title{
First Report of Cucurbit yellow stunting disorder virus in Cucurbits in Georgia, United States
}

Kiran R. Gadhave, ${ }^{\dagger}$ Bhabesh Dutta, Timothy Coolong, and Alton N. Sparks, University of Georgia, Tifton, 31793; Scott Adkins, USDA-ARS, U.S. Horticultural Research Laboratory, Fort Pierce, FL 34945; and Rajagopalbabu Srinivasan, University of Georgia, Tifton, 31793

Accepted for publication 16 November 2017.

Whitefly-transmitted viruses such as Cucurbit leaf crumple virus (CuLCrV) (Geminiviridae: Begomovirus), Squash vein yellowing virus (SqVYV) (Potyviridae: Potyvirus), and Cucurbit yellow stunting disorder virus (CYSDV) (Closteroviridae: Crinivirus), either independently or in mixed infections, pose a significant threat to cucurbit production in the southeastern United States (Adkins et al. 2011). Of these three viruses, only CuLCrV and SqVYV have been found in Georgia thus far (Adkins et al. 2011). For the first time in Georgia in fall 2016, symptoms resembling CYSDV infection were observed on cucumber (Cucumis sativus L.) and cantaloupe (Cucumis melo var. cantalupensis L.) in commercial fields in Colquitt County and on yellow squash (Cucurbita pepo L.) in a research plot in Tift County. Symptoms observed in the field typically included initial chlorotic spots in older leaves followed by interveinal chlorosis spreading to the entire leaf (Fig. 1). Symptomatic leaves were brittle and sometimes exhibited upward rolling. These symptoms, especially in cantaloupe, resembled those of magnesium deficiency. Later the chlorosis progressed through the plant, and infected plants were often stunted. Field observations indicated that the CYSDV-like symptoms were more prominent on yellow squash than on cucumber and cantaloupe.

CYSDV primarily infects squash, zucchini (Cucurbita pepo var. cylindrica), cantaloupe, and melons and is transmitted by the sweetpotato whitefly [Bemisia tabaci Gennadius (Hemiptera: Aleyrodidae)] (Wintermantel et al. 2009). The CYSDV genome contains two positive-sense single-stranded RNA segments (Aguilar et al. 2003). This virus has been documented in Texas, the western United States including Arizona and California (Kuo et al. 2007), and Florida (Adkins et al. 2011).

Foliar samples with CYSDV-like symptoms were collected from two commercial fields (cantaloupe $[n=8]$ and cucumber $[n=5]$ ) and research plots (squash $[n=5]$ ). The total RNA from symptomatic leaf tissue was extracted using an RNeasy Plant Mini Kit (Qiagen, U.S.A.). Initially, cDNA was synthesized from each RNA sample using a GoScript reverse-transcription system (Promega, U.S.A.). For all 18 samples, cDNA was amplified by conventional polymerase chain reaction (PCR) using CYSDV1 and CYSDV2 primers targeting the heat-shock protein 70 homolog (HSP-70h) gene (Livieratos et al. 1998). The cDNA of a subset of five samples (three cantaloupe, one cucumber, and one squash) was amplified using CYSCPf and CYSCPr primers targeting the coat protein gene (Rubio et al. 2001). Gel electrophoresis of PCR products revealed

${ }^{\dagger}$ Corresponding author: Kiran R. Gadhave; E-mail: krg@uga.edu

Current address for Kiran R. Gadhave: Department of Entomology and Plant Pathology, North Carolina State University, Raleigh, NC 27695; E-mail: krgadhave@ncsu.edu

(C) 2018 The American Phytopathological Society a 465-bp band for the HSP-70h gene (Fig. 2A) and a 755-bp band for the coat protein gene (Fig. 2B) in squash, cucumber, and cantaloupe samples. The obtained partial HSP-70h gene sequences (GenBank accession nos. KY404161 to KY404164) were 99 to $100 \%$ identical to corresponding sequences from California and Arizona CYSDV isolates (GenBank accession nos. EU596530 and FJ492808, respectively). Furthermore, the obtained coat protein gene sequences (GenBank accession nos. MF960766 to MF960770) were $100 \%$ identical to corresponding sequences from California and Arizona CYSDV isolates (GenBank accession nos. AF312799 and FJ492808, respectively). In addition, total RNA from the abovementioned samples $(n=18)$ was subjected to one-step reversetranscription (RT) real-time PCR with primers CYSDV-For and CYSDV-Rev targeting the 5'-untranslated region (UTR) of RNA2 (Gil-Salas et al. 2011). All the samples tested positive for CYSDV.

Ten whitefly-infected squash plants displaying CYSDV-like symptoms (with intact roots) were dug from a research plot in Tifton, Georgia. They were potted using native soil and placed in the greenhouse in insect-proof cages $(47.5 \mathrm{~cm}$ length $\times 47.5 \mathrm{~cm}$ width $\times 93 \mathrm{~cm}$ height) for $\sim 72 \mathrm{~h}$ at $25^{\circ} \mathrm{C}, 60 \%$ relative humidity, and $16 \mathrm{~h}$ light $/ 8 \mathrm{~h}$ dark photoperiod. The CYSDV infection status of the symptomatic plants was confirmed using RT-PCR with 5'-UTR primers. These plants also had $\mathrm{CuLCrV}$ symptoms, and testing using $\mathrm{CuLCrV}$ primers (Turechek et al. 2010) confirmed mixed

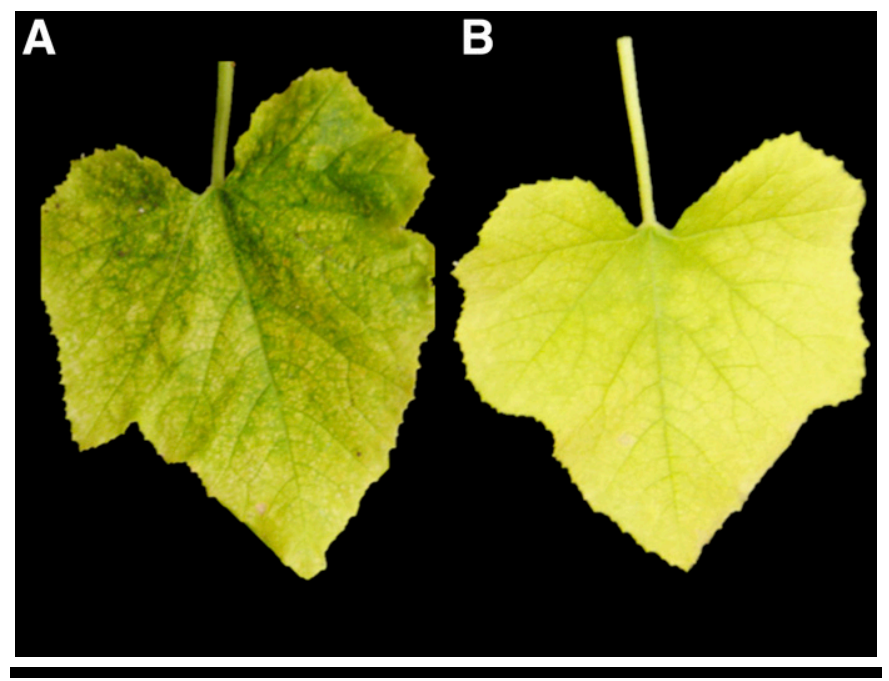

FIGURE 1

Characteristic symptoms on Cucurbit yellow stunting disorder virus infected squash leaves: $\mathbf{A}$, intermediately progressed infection with distinct chlorotic spots; and B, pronounced chlorosis of entire older leaf with light-green veins. 


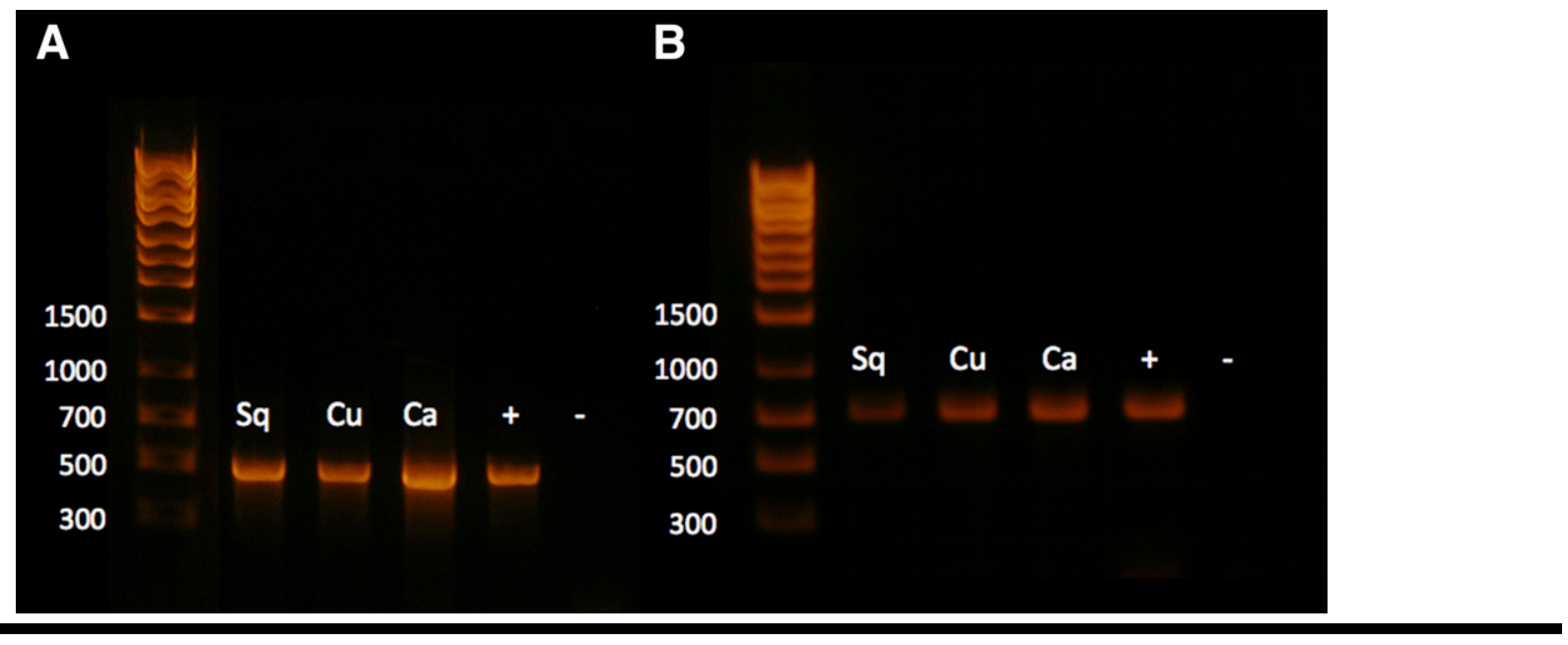

FIGURE 2

Conventional reverse-transcription PCR based detection of Cucurbit yellow stunting disorder virus in representative virus-infected squash (Sq), cucumber (Cu), and cantaloupe (Ca) samples using A, CYSDV1 and CYSDV2 primers targeting the 465-bp amplicon of the heat-shock protein 70 homolog gene, and B, CYSCPf and CYSCPr primers targeting the 755-bp coat protein gene. Positive $(+)$ and negative $(-)$ controls are indicated.

infections with CuLCrV. These plants were used as CYSDV inoculum and whitefly sources. After $72 \mathrm{~h}$ in the greenhouse, one infected plant with approximately 200 whiteflies was placed in an insect-proof cage along with three 2-week-old greenhouse-raised whitefly-free noninfected recipient squash plants (10 cages, each containing one infected and three noninfected recipient plants). The lack of CYSDV and CuLCrV infection in recipient plants before caging with infected plants was randomly confirmed using PCR. Because CYSDV is semipersistently transmitted and is retained in whiteflies for only a few hours, the additional $72 \mathrm{~h}$ feeding ensured CYSDV acquisition in the greenhouse by whiteflies. CYSDV acquisition by whiteflies was confirmed by using RT-PCR. By the end of the third week, all recipient plants $(n=30 ; 10$ cages $\times 3$ noninfected plants) displayed interveinal chlorosis and stunting. The CYSDV infection status of 10 symptomatic recipient plants was confirmed using PCR. The results demonstrated that whiteflies acquired CYSDV from field-collected CYSDV-infected plants and inoculated noninfected recipient squash plants. The inoculated plants also displayed leaf crumpling and tested positive for $\mathrm{CuLCrV}$.

This study for the first time provides evidence for the presence of CYSDV in Georgia. Thus, three whitefly-transmitted cucurbitinfecting viruses are now known in the state. Future research is required to evaluate the host range of CYSDV and its economic impact on cucurbit production in Georgia.

\section{Acknowledgments}

The authors acknowledge UGA extension agent Jenna Lee Licklighter, Colquitt County, and UGA extension coordinator Jeremy Kichler, Colquitt
County, for collecting and providing cantaloupe and cucumber foliar samples for testing.

\section{Literature Cited}

Adkins, S., Webster, C. G., Kousik, C. S., Webb, S. E., Roberts, P. D., Stansly, P. A., and Turechek, W. W. 2011. Ecology and management of whiteflytransmitted viruses of vegetable crops in Florida. Virus Res. 159:110-114.

Aguilar, J. M., Franco, M., Marco, C. F., Berdiales, B., Rodriguez-Cerezo, E., Truniger, V., and Aranda, M. A. 2003. Further variability within the genus Crinivirus, as revealed by determination of the complete RNA genome sequence of Cucurbit yellow stunting disorder virus. J. Gen. Virol. 84:2555-2564.

Gil-Salas, F. M., Peters, J., Boonham, N., Cuadrado, I. M., and Janssen, D. 2011. Yellowing disease in zucchini squash produced by mixed infections of Cucurbit yellow stunting disorder virus and Cucumber vein yellowing virus. Phytopathology 101:1365-1372.

Kuo, Y. W., Rojas, M. R., Gilbertson, R. L., and Wintermantel, W. M. 2007. First report of Cucurbit yellow stunting disorder virus in California and Arizona, in association with Cucurbit leaf crumple virus and Squash leaf curl virus. Plant Dis. 91:330.

Livieratos, I. C., Katis, N., and Coutts, R. H. A. 1998. Differentiation between Cucurbit yellow stunting disorder virus and Beet pseudo-yellows virus by a reverse transcription-polymerase chain reaction assay. Plant Pathol. 47: 362-369.

Rubio, L., Abou-Jawdah, Y., Lin, H., and Falk, B. 2001. Geographically distant isolates of the crinivirus Cucurbit yellow stunting disorder virus show very low genetic diversity in the coat protein gene. J. Gen. Virol. 82:929-933.

Turechek, W. W., Kousik, C. S., and Adkins, S. 2010. Distribution of four viruses in single and mixed infections within infected watermelon plants in Florida. Phytopathology 100:1194-1203.

Wintermantel, W. M., Hladky, L. L., Cortez, A. A., and Natwick, E. T. 2009. A new expanded host range of Cucurbit yellow stunting disorder virus includes three agricultural crops. Plant Dis. 93:685-690. 